\title{
A Review: Bacterial Diversity, Physicochemical Factors and Quality of Compost for White Button Mushroom Cultivation
}

\author{
Satish Kumar SINHA ${ }^{1}$, Tarun Kumar UPADHYAY ${ }^{1 *}$, Sushil Kumar SHARMA ${ }^{1}$, Manju SHARMA ${ }^{1}$ \\ ${ }^{1}$ School of Agriculture, Suresh Gyan Vihar University, Jaipur, Rajasthan, 302017, India \\ *corresponding author: tarun_bioinfo@yahoo.co.in
}

Bulletin UASVM series Agriculture 77(2) / 2020

Print ISSN 1843-5246; Electronic ISSN 1843-5386

DOI:10.15835/buasvmcn-agr: 2020.0010

\begin{abstract}
Composting is an aerobic biotic decomposition route that is governed by physicochemical and microbiological factors. The importance of bacterial flora throughout composting is well recognized. Though, diversity of the bacterial population during composting may differ with the composting material and nutrients content. Therefore, it is essential to study the different types of bacteria during the composting of various agricultural byproducts. The aim of this review is to evaluate the diversity of bacteria, physicochemical factors and quality of compost for cultivation of Agaricus bisporus (white button mushroom) for enhancement of better productivity.
\end{abstract}

Key words: bacteria, compost, quality, white button mushroom

\section{INTRODUCTION}

The mushrooms are spore bearing organisms, lack chlorophyll, and grow on decomposing matter as saprophytes. They derive nutrients through their mycelia. The white button mushroom (Agaricus bisporus) is best known in the world. It can be cultivated under favorable conditions. It is cultivated in North India in winter season. The ideal temperature for mycelial development is $22-28^{\circ} \mathrm{C}$ and that for fruit body development $15-18^{\circ} \mathrm{C}$. The substrate for cultivation is explicitly prepared compost (Pathak et al., 2013, Salmones et al., 2018).

Presently, more than thirty five mushrooms species have been commercially cultivated. The worldwide production of cultivated edible mushrooms was 495.127 metric tons in 1961. From 1961 to 2019, mushroom production increased to 456901 metric tons (source: UN com trade). In spite of the fact that Agaricus bisporus (button mushroom) still holds the most demand in world, now days China is global leader in cultivating mushroom.

The nutritional value of edible mushroom and the bioactive compounds they contain, make mushrooms a healthy food (Andrade et al., 2014). Medicinal significance and dietary nature of white button mushroom is well documented (Keleș et al., 2011; Changizi et al., 2012; Muszynska et al., 2017, Verma et al., 2013).

Composting is a process of transforming organic materials of either plant or animal origin into simpler compounds (Scialabba et al., 2017). It is an aerobic process, during which organic material is biologically decomposed by microorganisms (Jurak et al., 2015). The end product should not contain pathogens or viable seeds, and it should be stable and suitable for use. Many factors such as moisture, organic matter, carbon content, EC, $\mathrm{pH}, \mathrm{C}: \mathrm{N}$ ratio, and microorganism, temperature, 
affect the composting process and ultimately the end product (Gebeyehu and Kibret, 2013; Jusoh et al., 2013; Lim et al., 2013).

The problem is that tons of biodegradable organic waste is being generated from agriculture like parali, sugarcane straw, maize straw, wheat straw in the country, creating disposal problems. Through composting mediated by microorganisms that utilize organic waste, the organic matter can become useful in agriculture / horticulture. Composting is one of the most promising technologies to treat waste in a more economical way. For many centuries composting has been used as a means of recycling organic matter back into the soil to improve soil structure and fertility. Composting is a natural process that turns organic material into a nutrient-rich substrate. This is a wonderful conditioner for soil. During composting process, microorganisms such as bacteria and fungi, breakdown complex organic compounds into simpler forms and release nutrients. The turning operation mixes the composting materials, enhances passive aeration and makes conditions for aerobic decomposition. Mixing of substrates has a very important role in composting. During composting some bacteria produce enzymes that breakdown the cell wall elements of the plant's organic material. This cause parts of organic material to start rotting. Some bacteria also release some toxins during decomposition. Careful and continuous monitoring of microbial activity during composting is the key factor of successful decomposition. This can be done through regular turning and mixing of substrates (Navarro et al., 2014).

\section{Composting}

Composting is an environmentally acceptable method that turns agro-waste and organic residues of animal origin into suitable materials for re-utilization. It is an aerobic biological process which uses naturally occurring microorganisms to convert biodegradable organic matter into humus like substance. The process destroys pathogens, converts $\mathrm{N}$ from unstable ammonia to stable forms, reduces the volume of waste and improves the nature of the waste. The effectiveness of the composting process is influenced by factors such as temperature, oxygen supply (i.e. aeration) and moisture content. Composting is the decomposition of organic wastes in the presence of oxygen; produce from this process includes $\mathrm{CO}_{2}$, $\mathrm{NH}_{3}$, water and heat. Effective composting require right blend of ingredients and conditions. These include moisture content of around $65-70 \%$ and C:N ratio 23.18 (Sinha et al., 2020, Sarkar and Chanda, 2016; Sofi et al., 2016).

\section{Phases of Composting}

According to Singh and Jha, the four phases of composting include: [1]. Mesophilic phase; [2]. Thermophilic phase; [3]. Cooling phase and [4]. Maturing or Curing phase (Singh and Jha, 2014).

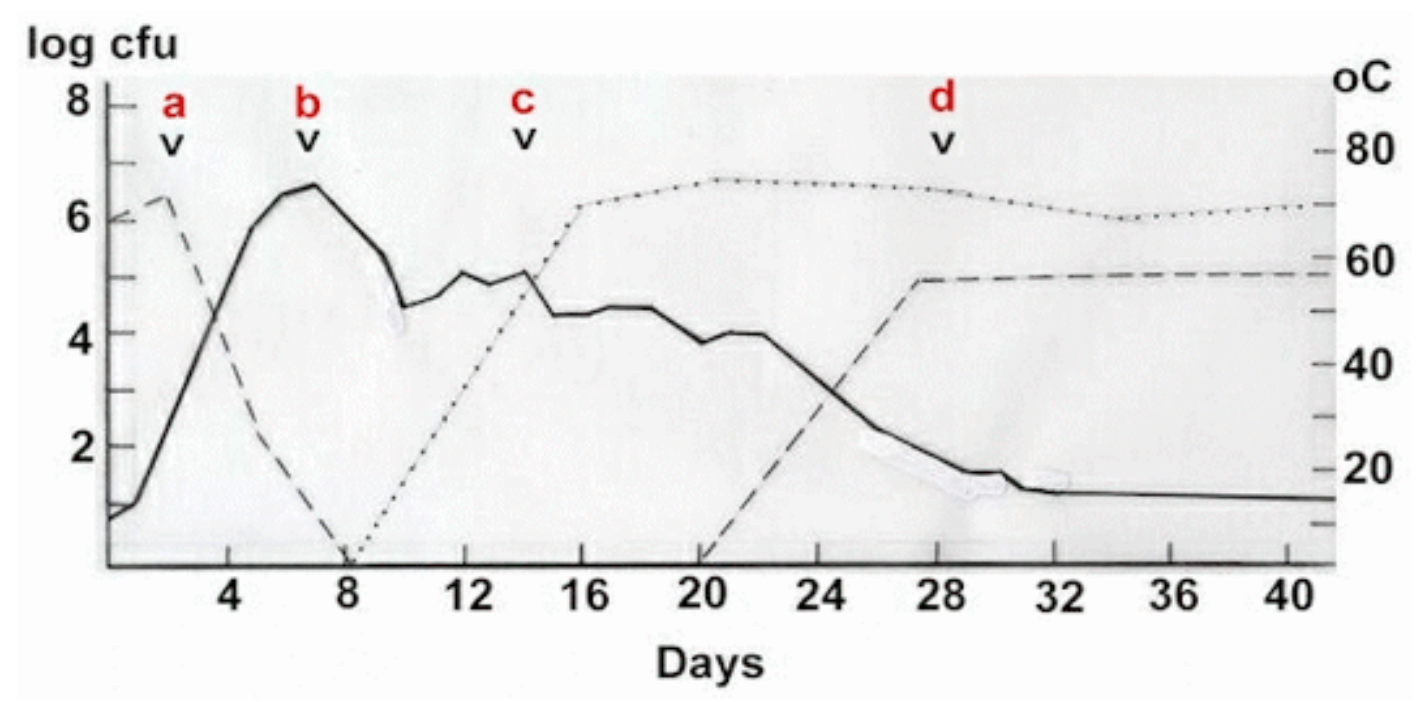

Figure 1. Changes in temperature (solid line) and populations of mesophilic fungi (broken line) and thermophilic fungi (dotted line) in wheat straw compost (Source: http://archive.bio.ed.ac.uk/jdeacon/microbes/thermo.htm). 


\section{[i]. Mesophilic phase}

In this stage compost bacteria combine carbon with oxygen to produce $\mathrm{CO}_{2}$ and energy. Some of the energy is used by the microorganisms for reproduction and growth, the rest is given off as heat. When mesophilic bacteria proliferate, the temperature of the composting mass is raising up to $44^{\circ} \mathrm{C}$. This is the first stage of composting process. These mesophilic bacteria can include $E$. coli and other bacteria from the human intestinal tract, but these soon become increasingly inhibited by the temperature, as the thermophilic bacteria take over in the transition range of $44-52^{\circ} \mathrm{C}$ (Gaur et al., 2017).

\section{[ii]. Thermophilic (Heating) Phase}

During this phase, the temperature in the heap rises to $60-70^{\circ} \mathrm{C}$. Most of the decomposition occurs during the heating phase. In this phase, it is mainly bacteria which are active. The high temperature is a result of energy released during conversion of easily decomposable ingredients by the bacteria. The warm temperature is a typical and important part of the composting process. The heat destroys diseases, pest, weed roots and seeds. During this phase of composting process, the bacteria have a very high oxygen demand due to the rapid development of their population. High temperatures in the heap signed that there is an adequate supply of oxygen for the bacteria. If there is not enough air in the heap, bacterial development will be hindered and the compost will develop an unpleasant odour. Humidity is very essential to the composting process, as bacteria require humid conditions for their activities. The need for water is greatest during the heating phase because of high biological activity and strong evaporation occurring during this phase. As the heat increases, the $\mathrm{pH}$ of the compost heap rises (Teshome, 2017).

\section{[iii]. Cooling Phase}

Once the materials are digested by the bacteria, the temperature in the compost heap declines slowly and remains at $25-45^{\circ} \mathrm{C}$. The decline in temperature, fungi settle and start the decomposition of straw, fibers and other organic material. As the temperature drops, the composting material declines (i. e. acidity increases) (Teshome, 2017).

\section{[iv]. Maturity Phase}

During the maturing phase mineralized nutrients, humic acids and antibiotics buildup. At the end of this phase the compost has lost about half of its original volume, is the dark in color, fertile and ready to use. In the maturity phase, the compost needs much less water than in the heating phase (Eiri, 2018).

\section{Factors affecting the composting process}

The breakdown of organic matter during composting is a constantly change in moisture, oxygen demand, nutrients, temperature, and $\mathrm{pH}$ (Teshome, 2017).

\section{[i]. Moisture}

At too high temperature water between the particles of material gets waterlogged, preventing movement of air within the heap. The optimum moisture content of ingredients for composting is $50-60 \%$. Water is produced during the composting process by the microorganisms and is lost by evaporation into the air stream. It may be necessary therefore to provide additional moisture to the compost heap (Singh and Nain, 2014).

\section{[ii]. Oxygen demand}

An adequate supply of oxygen to all parts of a compost heap is essential and flush out the carbon dioxide produced. Oxygen supply to heap by turning the material and flush out the $\mathrm{CO}_{2}$ (Andrade et al., 2013).

\section{[iii]. Nutrients}

The composting process depends upon the activity of microorganisms which require a source of carbon to provide energy and material for new cells, together with a supply of nitrogen for cell proteins. Nitrogen is the most important nutrient. It is desirable that the ratio of carbon to nitrogen is in the range of 25 to 35/1. The simplest method of adjusting the $\mathrm{C} / \mathrm{N}$ ratio is to mix together different materials of high and low carbon and nitrogen contents. Phosphorus is less important nutrient in composting than nitrogen but sometimes deliberately added (Gaur et al., 2017).

\section{[iv]. Temperature}

When organic material is mixed for composting some of the energy released by the breakdown of the material causes a rise in temperature. The normal temperature-time curve of a compost heap is shown in the fig. 2 (Smith and Collins, 2007).

When the composting material passed through the temperature peak, the heap reaches stability at which the easily converted materials broken down and it is met the highest level of oxygen demand. While cooling down, straws and stalks get decomposed; hence hemicellulose and cellulose break down, into simpler sugar components, for the microorganisms. It is necessary to kill all 


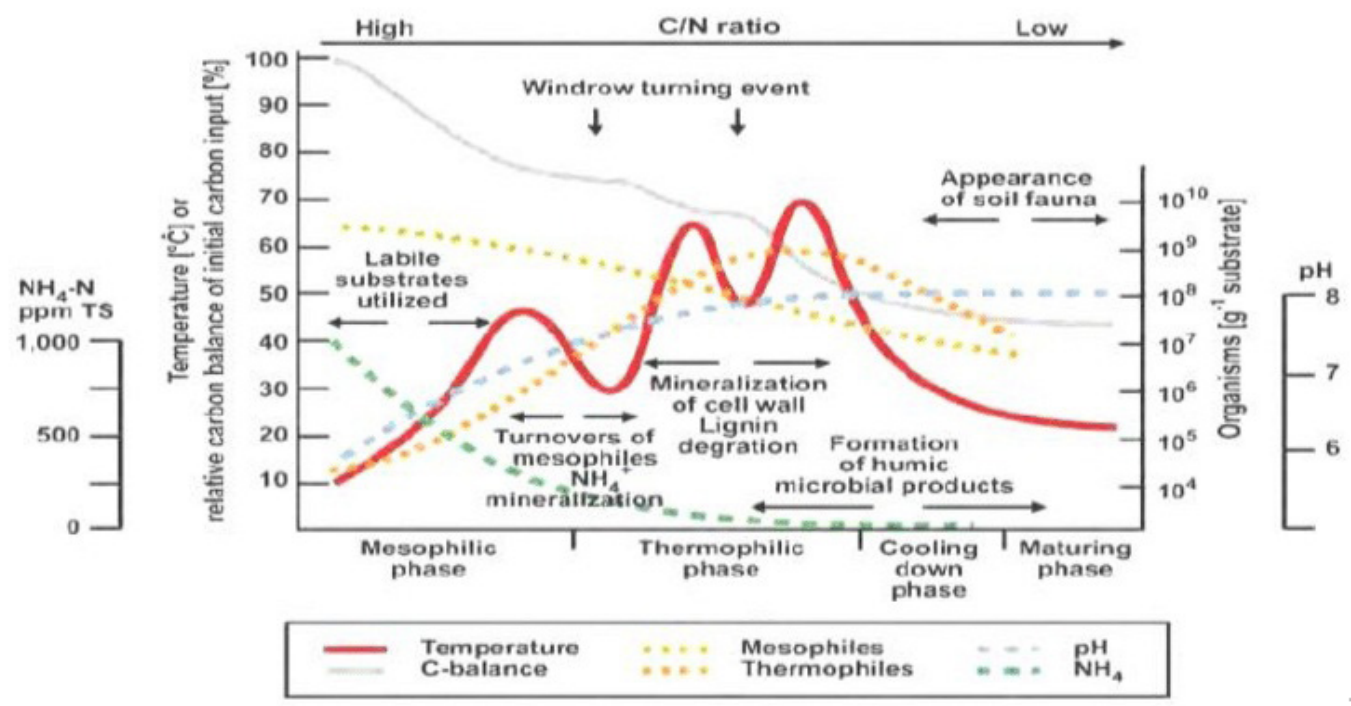

Figure 2. During Composting process varied Temperature, $\mathrm{pH}, \mathrm{NH}_{4}$ and Carbon composting (Lechner et al., 2005)

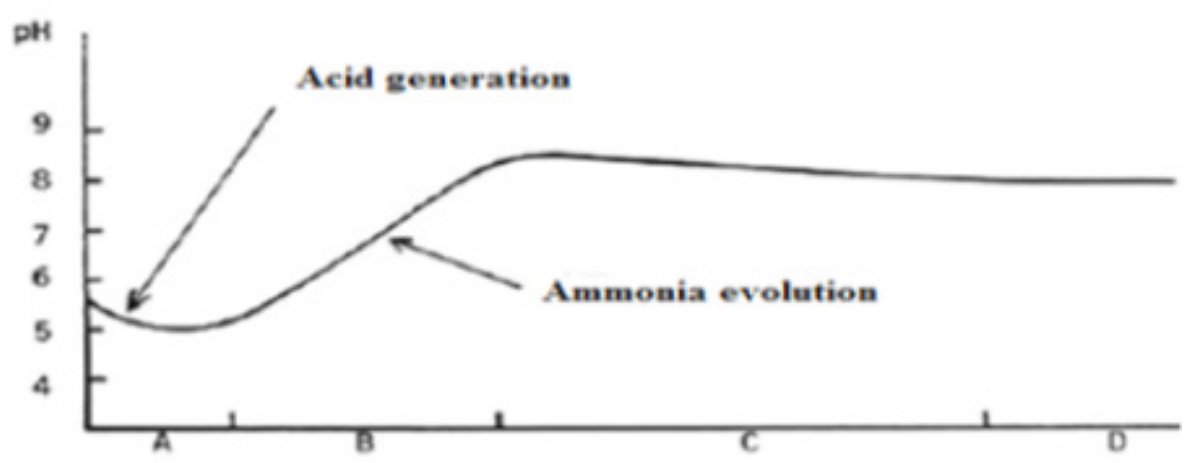

A- Mesophilic

C-Cooling
B.Thermophilic

D-Maturing

Figure 3. The pH variation in a compost heap (Dalzell et al., 1987)

weeds and disease-causing by microorganisms (Singh and Jha, 2014).

\section{[v]. pH}

The composting $\mathrm{pH}$ depends on the source materials and varies in each phase of the process (from 4.5 to 8.5). In the early phases of the process, the $\mathrm{pH}$ was acidified by the formation of organic acids. In the thermophilic phase, due to the conversion of ammonium into ammonia, the $\mathrm{pH}$ rises; the medium is alkalized to finally stabilize at values close to neutral. The $\mathrm{pH}$ determines the survival of microorganisms and each group has optimal $\mathrm{pH}$ for growth and multiplication. Most bacterial activity occurs at pH 6.0 - 7.5, while most fungal activity occurs at $\mathrm{pH} 5.5$ to 8.0. The ideal range is from 5.8 to 7.2. (see fig. 3) (Dalzell et al., 1987).

\section{Composting Methods and Turning}

Turning means aerating of the compost pile. The materials in a compost heap are the deciding factors whether composting is an acceptable practice in a community. It helps mix the various ingredients in the heap. It aids aeration where air has difficulty in penetrating to the middle of the heap. It also gives an opportunity to moisten the material. Due to turning the mesophilic, thermophilic 
and cooling down stages take place in about 7-10 days (Singh et al., 2011). There are two methods of composting adopted for Agaricus bisporus production: LMCT (Long Method of Composting and Turning) and SMCT (Short Method of Composting and Turning) (Singh et al., 2011).

\section{Turning)}

[i]. LMCT (Long Method Composting \&

This method usually takes 26-28 days. On first day, wheat straw and paddy straw are mixed with fertilizer and bran measuring heap size 6 feet $\times 3$ feet $\times 4$ feet.

First turning of compost gets carried out on $6^{\text {th }}$ day with addition of $5 \mathrm{~kg}$ molasses and heap is formed again. The second turning is done on the $10^{\text {th }}$ day and $150 \mathrm{~g}$ furadan $3 \mathrm{G}$ (Carbofuran) is mixed. Third turning is given on $13^{\text {th }}$ day and mixed with required quantity of gypsum. Likewise, the fourth, fifth, sixth turning done on $16^{\text {th }}, 19^{\text {th }}$ and $22^{\text {nd }}$ day respectively. On $25^{\text {th }}$ day, $25 \mathrm{~g}$ BHC - Benzene Hexa Chloride, $10 \%$ is added during seventh turning. Filling of compost is done on $28^{\text {th }}$ day. If there is smell of ammonia, then it is turned and kept open for one to two days more. However the excess ammonia will disappear and the compost will be ready for further use. Compost preparation is very important process for cultivation (Andrade et al., 2013). Various types of formula are used for composting and used by organizations such as ICAR, NCMRT, IIHR, and CCSHAU(Choudhary Charan Singh Haryana Agricultural University) (Singh and Jha, 2014).

[ii]. SMCT (Short method of Composting and Turning)

In this method all ingredients are mixed as per LMCT. First turning is given on $2^{\text {nd }}$ day. Similarly $2^{\text {nd }}$ turning on $4^{\text {th }}$ day and $3^{\text {rd }}$ turning on $6^{\text {th }}$ day. However, on $8^{\text {th }}$ day of compost transfer for pasteurization and heating.

This method is comparatively better than LMCT due to several aspects: compost preparations take 14-18 days where as LMCT take 26-28 days; production of mushroom per unit compost is almost double; manpower requirement is also less as compared to the LMCT.

The method is carried out into two steps: first pasteurization and second heating (Sinha et al., 2020).

\section{Pasteurization}

Mixed ingredients of compost on $8^{\text {th }}$ day transferred into tunnel/room. The size of tunnel or in- sulated room is $36 \mathrm{ft}$. $\times 9 \mathrm{ft} . \times 12 \mathrm{ft}$. for a capacity to produce 20-22 tons. A boiler capacity of $15 \mathrm{~kg}$ / circulates steam with a capacity of $145 \mathrm{rpm}$ to produce $150-200 \mathrm{~m}^{3}$ air / h. (Eiris, 2018).

\section{Heating}

Pasteurized compost on $9^{\text {th }}$ day is transferred into heating room. In heating room compost is placed into number of 250 trays with tray size 100 $\mathrm{cm} \times 50 \mathrm{~cm} \times 15 \mathrm{~cm}$, room size 24 feet $\times 16$ feet $\times 8$ feet on the stand of $15 \mathrm{~cm}$ long. About 12-15 $\mathrm{h}$ of compost filling in chamber the temperature of compost starts rising and once reached up to $48-50^{\circ} \mathrm{C}$. This temperature is maintained for 36-40 hours. With self-generation of heat of the compost mass without steam injection. Thereafter temperature of compost rises up to $57^{\circ} \mathrm{C}$ by injecting the steam. Temperature is maintained for 6-8 hours. During $10^{\text {th }}$ to $14^{\text {th }}$ days temperature is gradually lowered down to $45-50^{\circ} \mathrm{C}$ till no traces of ammonia get detected in the compost. This may take 3-4 days. On $15^{\text {th }}-18^{\text {th }}$ day, when the compost is free from ammonia, full fresh air is introduced, the compost temperature cools down to $25^{\circ} \mathrm{C}$ and is ready for mushroom cultivation. Various compost formulations can be used for button mushroom cultivation i.e. natural compost, synthetic compost and CCSHAU (Chaudhary Charan Singh Haryana Agricultural University) (Andrade et al., 2013; Borkar and Nisha, 2016; Singh and Jha, 2014).

\section{Bacteria Associated with the Compost}

High concentration of organic matter contains many micro fungi and bacteria. However most parasitic organisms are killed during heating phase of compost, a few spore -forming bacteria, if present, can survive temperature more than $100^{\circ} \mathrm{C}$. The composting material like coastcross straw, Saccharum officinarum bagasse and other nutrients are used for farming of Agaricus brashiliensis. Total composting period lasts for 14 days followed by two-step steam pasteurization at $55-65^{\circ} \mathrm{C}$ for $15 \mathrm{~h}$. Results showed that mainly Bacillus and Paenibacillus spp. and the members of Entrobacteriaceae with average population density of $3 \times 10^{8} \mathrm{CFU} / \mathrm{g}$ are present. Similarly, Actinomycetes, Streptomyces populations reach between $2-3 \times 10^{8} / \mathrm{CFU} / \mathrm{g}$. The other filamentous fungi population density is found lower. Aspergillus fumigatus are detected in compost from first day to fourteen days (Silva et al., 2009). Concertation of dehydrogenases determined by $1 \%$ triphenyltetrazolium chloride as substra- 
tum showed that in all composting process Entrobacteriaceae was eliminated. Inactivation of bacteria from Enterobacteriaceae family and reduction of Clostridium perfringens bacteria testify to high level of hygienic effectiveness of compost processing (Wolna and Sawicka, 2009). Bacterial identification can follow the specific standard method (Bull et al., 2010; Bull et al., 2012). The growth of denitrifying atmosphere is very favorable to denitrifying bacteria. $P$. denitrificans could denitrify nitrite when their concentrations were lower $(10 \mathrm{mM})$. A toxic outcome of nitrite at high concentration dropped the growth of Pseudomonas denitrificans and other denitrifies. $P$. denitrificans first decrease nitrate to nitrite under denitrifying conditions and then, after reducing most of the nitrate, initiates the subsequent reduction from nitrite to the nitrate and subsequent reduction from nitrite to $\mathrm{N}_{2}$ (Miyahara et al., 2010).

Bacterial profile in casing materials are used for Agaricus bisporus cultivation. The casing materials were collected from mushrooms growing farm. In casing materials are used wattle bark, coir, filter cake, bagasse and lime added to stabilize the $\mathrm{pH}$ from acidic to $\mathrm{pH}$ 7. 0 . The methodology was used for DGGE (Denaturing Gradient Gel Electrophoresis) analysis for bacterial characterization. The bacteriological study was conducted in three different stages: first casing, second pinning and third harvesting. Results showed that bacterial population were countless in the peat based mixture, which contained industrial discarded materials, than in peat alone. Results showed that numerous types of the bacterial population identified in peat casing materials and as potential bacterial like Flavobacterium, alpha-Proteobacterium, Pseudomonas, gammaProteobacterium, beta-Proteobacterium, and deltaProteobacterium community supported in the pinhead initiation process (Siyoum and Korsten, 2010).

Choudhary (2011) studies in casing soil of Agaricus bisporus showed that Pseudomonas and Acinetobacter of the $\gamma$-proteobacteria were the maximum encountered species. Other several genera and species contained are Pseudomonas mevalonii, B. subtilis, Bacillus licheniformis and Paenibacillus lentimorbus. Another two microbial flora Stenotrophomonas sp. and Sphingobacterium multivorum were also examined. In addition two potentially novel types within the genera Microbacterium \& Stenotrophomonas and various dynamics of microorganism was found during maturation phase of composting (Choudhary, 2011; Villar et al., 2016).

Button mushroom has most important economic value, medicinal characteristics and is rich in nutrition. Wheat straw and sugar cane bagasse are selected for compost. Results stated that a diverse population consisting mainly of Bacillus sp., followed by Ochrobactrum sp., Arthrobacter arilaiti, Stenotrophomonas maltophilia are responsible for the degradation of the physical, chemical and fibers characteristics of the compost (Johri, 2011).

Discoloration of Agaricus bisporus (white button mushroom) due to pathogenic bacteria was reported by Abou-Zeid (2012). Superficial brown discolored caps of button mushroom collected and from that 27 bacterial isolates were identified. Bacterial isolate were identified with Biolog identification system and WLA (White Line Assay) and was divided into two groups. First group contained 19 bacterial isolates which responded to Pseudomonas reactans and Pseudomonas tolaasii. These two bacteria belong to strain NCPPB1311. Second group belongs to strain JCM21583. Third group comprises 6 bacterial isolates. In this group first subgroup contained Pseudomonas tolaasii and Pseudomonas gingeri and in second four isolates of Pseudomonas fluorescens (three strains) and Pseudomonas marginalis (one). First treatment with 10 $\mu \mathrm{l}$ containing $108 \mathrm{CFU} / \mathrm{ml}^{-1}$ of $P$. tolaasii and P. reactans showed light brown color and $50 \mu$ containing $108 \mathrm{CFU} / \mathrm{ml}^{-1}$ of P. tolaasii significantly visible typical brown blotch indicator on the fresh mushroom sporophores whereas $P$. reactians showed superficial brown discoloration after inoculation with $100 \mu \mathrm{l}$ of same concentration. This study indicates that mixture of both bacterial suspensions increased the discoloration on the pileus. Research article stated that this is the first pathogenicity test carried out on the Agaricus bisporus for pathogenicity with $P$. tolasii and $P$. reactans. Some of the significant nitrogen fixing bacteria beneficial for agriculture are from genera: Achromobactor, Acetobacter, Alcaligenes, Arthrobacter, Azospirillum, Azomonas, Beijerinckia, Azotobacter, Clostridium, Corynebacterium, Bacillus, Derxia, Herbaspirillum, Klebsiella, Enterobacter, Pseudomonas, Rhodospirillum, Xanthobacter, Rhodopseudomonas. Some of 
other phosphate solubilizing bacteria like Bacillus cereus, B. polymyxa, B. pumulis, Pseudomonas fluorescens, $P$. aeruginosa play very important role in the soil for release the phosphate. According to other studies it was stated that lignin degrading enzymes like lignin peroxidase, manganese peroxidase, glyoxal oxidase are present (Girisham et al., 2012).

Swain et. al (2012) conducted a study on the Bacillus subtilis from cow dung to investigate the role in phosphate solubilization. Bacillus subtilis grows at $<50^{\circ} \mathrm{C}$ and are known as thermo-tolerant bacteria. Results showed that Bacillus subtilis successfully solubilized phosphorus in soil. Therefore, its very useful bacteria for agriculture (Stanojevic et al., 2016; Swain et al., 2012).

Chung et al. (2014) conducted studies on Pseudomonas tolassii in Agaricus to identify pathogenic characteristics. The major decreasing quality of mushroom are due to infections of mushrooms and it can be improved by various washing treatment (Gupta and Bhat, 2016). Pseudomonas tolaasii produces peptide toxin known as tolaasin. In total seven strain of Pseudomonas tolaasii were isolated from Agaricus bisporus (Chung et al., 2014).

The microbiological additive effects on composting was studied by Lim et al. (2013). In this study various factors like $\mathrm{C}: \mathrm{N}$ ratio, temperature, moisture, $\mathrm{pH}$, bacteria, fungi, and Actinomicetes were studied. The inoculation of microbes in compost increase soil fertility and crop production. Researcharticle showed that differentbacteria from compost like Pseudomonas, Cohnella, Cellulomonas, Paenibacillus, Bacillus, B. licheniformis, B. subtilis, B. coagulans, B. stearothermophilus, B. sphaericus, Thermotogae and fungi like Aspergillus fumigatus, Malbranchea cinnamomea, Ganoderma colossum and Heterobasidion annosum were present in various composts. In addition of additives the use of compost also suppress diseases and increase plant stress acceptance capacity. Use of compost as organic manure enhances soil fertility and reduced production of toxins in the soil (Lim et al., 2013; Reddy et al., 2017).

The odour in compost plays vital role and various impacts on $\mathrm{pH}$ and microbial composition. During composting, specific odor occurs due to low decomposition process. Actinobacteria (Corynebacterium), Bacillales (Bacillus infernus, B. thermoamylovorans), Lactobacillus species
(L. amylovorus, L. brevis, L. plantarum) were found in compost. Other genera and species like Bacillus pumilus, Thermoactinomyces, $T$. chromogena, T. curvata and Thermobifida fusca (Thermomonospora) were also detected. During investigation it was noticed that $\mathrm{pH}$ ranges from 6.5 to 6.0 while nitrate, TVOC (Total Volatile Organic Compounds) and organic acids were not detected. Spent mushroom substrate are also useful to incorporate in white button mushroom production. Results finally concluded that reduction in odour, stable $\mathrm{pH}$ aeration and additives are usually required (Rossiana et al., 2017; Sundberg et al., 2013).

Composting is the biological degradation and stabilization of an organic substrate under the conditions that permit growth of thermophilic microorganisms and that generates heat as a natural outcome. Cellulolytic bacteria degrade cellulose.Others bacterial strains arewell-known to solubilize and change the lignocellulosic structure extensively. Mesophilic bacteria Cytophaga and Cellulomonas are known to degrade cellulose. Other hemicellulose and cellulose degrader mesophilic bacterial species are Bacillus megaterium, Bacillus polymyxa, Bacillus brevis, Bacillus firmus, Bacillus cerus, Bacillus licheniformis, Bacillus circulans, Bacillus subtilis and Bacillus pumilus (Singh and Nain, 2014).

Growth promoting and anti-microbial activity of bacteria from fruit body of Agaricus bisporus has a very significant role in environmental development of cultivated mushrooms worldwide. According to Zheng et al. (2018) mushroom growthpromoting microorganism are isolated from earth soil and compost. A total of 55 microorganisms were isolated and categorized from A. bisporus. Around 9 strains of Actinomycetes were identified while other microorganisms were analyzed by 16S rRNA and 16S rRNA factor sequence. No less than 11 isolated groups were gram positive true bacteria like Lysinibacillus, Paenibacillus, Pandorea genera while other five microorganism taxa were gram-negative bacteria. Some bacteria identified are involved in several biological processes including the transformation, mineralization and solubilization of soil phosphate. Trial materials were collected from the farming fields and tested in the laboratory by phylogenetic identification with 16SrRNA and PVK (Pikovaskayas) medium. Results showed that four iPSB strains with the 
highest phosphate solubilizing capacity were representative. It was showed that Bacillus megaterium phosphate solublization capacity is higher than other genera including Streptomyces, Arthrobacter and Pseudomonas. The Bacillus megaterium isolates Y1412, Y95, Y99 and Y924 released more than $130 \mu \mathrm{g} / \mathrm{mL}^{-1}$. Succinic acid concentration were powerfully and linearly correlated with phosphate release $\left(\mathrm{R}^{2}=0.7908\right.$; $\mathrm{P}$ value of, 0.001$)$ (Zheng et al., 2018).

Compost management design has direct potential impact on the mushroom production, control of Lycoriella ingenua larvae and the environment (Cloonan et al., 2016; Jayaprakash et al., 2018).

It was also stated that compost is very important process to recycle nutrients like nitrogen and phosphorus. Methods of microbial analysis of compost and investigations about the relationship between the indigenous microorganisms, foodborne pathogens, $\mathrm{C}: \mathrm{N}$ ratio, moisture and temperature are all needed to ensure that compost can be used as a biological soil amendment to grow fruits and vegetables intended for human consumption (Gurtler et al., 2018).

\section{Compost Quality}

The intent and need to report qualities of compost scientifically is a natural outcome of growth of the compost industry. The concept of establishing quality standards specific to compostis a very important factor. Recently, several European countries have adopted specific standards and many other countries are in the process. The only existing quality guidelines specific to compost are presently promulgated by such specific agencies. However, compost, a product that contains nutrients and organic matter, is not subject to any systematic rules for reporting its content, qualities or potential risks. There are no labelling rules and no published guidelines to establish such rules, unless if the compost is sold as fertilizer. Following quality composition of compost permissible limits are accepted by various countries (Table 1 , Table 2 , Table 3, Table 4).

\section{Cultivation of White Button Mushroom} and Bacteria

The production of Agaricus bisporus depends on spores and spawn. When the spores of the mushroom fungus fall on the suitable substrate and the conditions are favorable, they germinate and form a mat of mycelium. This is dug out and use as spawn. Second type of spawn is "Flake Spawn" when the beds fully covered with mycelium before a crop of mushroom appears. Then the compost is collected, broken, dried and used as fresh to inoculate other new bed. Third type of spawn known as "Brick Spawn" when a mass consisting of horse and cow dung manure and loam is mixed with water, tapped out into layer two inches thick and cut into pieces when it half dry. These pieces are then inoculated with old spawn by making a hole in each and after the spawn grows through the entire piece it is dried and sold as Brick Spawn. Fourth type of spawn is known as "Grain Spawn" and is suitable and worldwide accepted for the preparation Agaricus bisporus spawn. The grain is boiled with equal volume of water till the water dries out. Then grain mixed with calcium carbonate, $8 \%$ by the grain weight. The mixed grain is filled in a wide mounted bottle, plugged tightly and sterilized for two consecutive days at $15 \mathrm{lbs}$ p.s.i for 30 minutes. After two days of sterilization the bottle inoculated with the culture of mushroom at $25 \pm 1^{\circ} \mathrm{C}$ for 21 days. By combining $2 \%$ gypsum with $6 \%$ lime by grain weight gives the best results in the process of making grain spawn for Agaricus bisporus (Bahl, 2018).

Prepared spawn is stored at $2^{\circ} \mathrm{C}$ for 68,128 and 206 days. The compost is filled in wooden trays of convenient size having four pegs on four corners or it can be put on shelves. Spawn trays are covered with paper and stacked. Room temperature should be maintained between $22-25^{\circ} \mathrm{C}$ during spawn run. Compost is covered with a thin layer of soil after 10-15 days. Most suitable thickness of the casing is 1-1.5 inches for button mushroom production. After casing, the mushroom can be expected between 5-20 days. A fine water spray is given to casing soil to maintain moisture $70-80 \%$ of humidity. Room temperature should be kept between $14-18^{\circ} \mathrm{C}$ for better yield. Pin head formation happens after 7-8 days. Hence an interval of 8-10 days mushroom occurs between flushes. The maximum mushroom production can be considered at 6 week in order to be economically viable (Singh et al., 2011).

Bacterial blotch diseases is one of the most common in Agaricus bisporus and is caused by Pseudomonas tolaassi. Agaricus bisporus cap sunken spots are irregular and colour becomes yellowish to dark brown. The main source of infection is the casing soil. Preventive spray with 9 
Table 1. Nutrients limit in compost for mushroom cultivation (Roman et al.,2015)

\begin{tabular}{ccc}
\hline No & Nutrients & $\%(\mathrm{~g} / \mathrm{kg})$ \\
\hline 1 & Nitrogen & $0.3-1.5(3 \mathrm{~g}-15 \mathrm{~g} / \mathrm{kg}$ of compost $)$ \\
\hline 2 & Phosphorus & $0.1-1.0(1 \mathrm{~g}-10 \mathrm{~g} / \mathrm{kg}$ of compost $)$ \\
\hline 3 & Potassium & $0.3-1.0(3 \mathrm{~g}-10 \mathrm{~g} / \mathrm{kg}$ of compost $)$ \\
\hline
\end{tabular}

Table 2. Microbiological limits according to different standards (Brinton, 2000)

\begin{tabular}{|c|c|c|c|c|c|}
\hline \multirow{2}{*}{ Microorganism } & \multicolumn{2}{|c|}{ Chile Nch 2008/04 } & \multirow{2}{*}{$\begin{array}{c}\text { EU (European } \\
\text { Union) }\end{array}$} & \multirow{2}{*}{$\begin{array}{c}\text { Colombia } \\
5167 / 04\end{array}$} & \multirow{2}{*}{$\begin{array}{c}\text { Mexico } \\
\text { NTEA- } \\
\text { 006-SMA } \\
\text { RS2006 }\end{array}$} \\
\hline & A & B & & & \\
\hline $\begin{array}{l}\text { Fecal Coliform } \\
\text { (Dry base }\end{array}$ & $\begin{array}{l}<1000 \mathrm{~g} \\
\mathrm{NMP} / \mathrm{g}\end{array}$ & $\begin{array}{l}<2000 \\
\mathrm{NMP} / \mathrm{g}\end{array}$ & $\begin{array}{l}<1 \times 10^{3} \\
\mathrm{NMP} / \mathrm{g}\end{array}$ & $\begin{array}{c}<1000 \mathrm{UFC} / \mathrm{g} \\
\text { Total Entro } \\
\text { bacterial }\end{array}$ & $\begin{array}{l}<1000 \\
\mathrm{NMP} / \mathrm{g}\end{array}$ \\
\hline Salmonella sp & $\begin{array}{l}\text { Absent } \\
\text { in } 25 \mathrm{~g} \text { of } \\
\text { product }\end{array}$ & $\begin{array}{l}\text { Absent } \\
\text { in } 25 \mathrm{~g} \text { of } \\
\text { product }\end{array}$ & $\begin{array}{c}\text { Absent in } 25 \mathrm{~g} \text { of } \\
\text { product }\end{array}$ & $\begin{array}{c}\text { Absent in } 25 \mathrm{~g} \\
\text { of product }\end{array}$ & $<3 / g b s$ \\
\hline Enterococcus faecalis & - & - & $1000 \mathrm{NMP} / \mathrm{g}$ & ND & - \\
\hline Visible helminth eggs/Ascaris & Absent in $1 \mathrm{~g}$ & Upto 1 in $1 \mathrm{~g}$ & Absent in $1 \mathrm{~g}$ & ND & $<10 / \mathrm{g} \mathrm{bs}$ \\
\hline
\end{tabular}

Note: NMP-Most Probable Number, UFE-Colony formation units, bs- Dry base

Table 3. Heavy Metals limits (mg/kg) compared EC State verses USA (Brinton, 2000)

\begin{tabular}{lccc}
\hline Metal & Symbol & EU-Range & USA bio solids \\
\hline Cadmium & $\mathrm{Cd}$ & $0.7-10$ & 39 \\
\hline Chromium & $\mathrm{Cr}$ & $70-200$ & 1200 \\
\hline Copper & $\mathrm{Cu}$ & $70-600$ & 1500 \\
\hline Mercury & $\mathrm{Hg}$ & $0.7-10$ & 17 \\
\hline Nickel & $\mathrm{Ni}$ & $20-200$ & 420 \\
\hline Lead & $\mathrm{Pb}$ & $70-1000$ & 300 \\
\hline Zinc & $\mathrm{Zn}$ & $210-4000$ & 2800 \\
\hline
\end{tabular}


Table 4. General factors limit for compost (Gaur et al. 2017)

\begin{tabular}{cc}
\hline Condition & Preferred range \\
\hline Moisture $\%$ & $68-72$ \\
\hline C:N ratio & $17.6-20.47$ \\
\hline Oxygen $\%$ & $>10$ \\
\hline pH & $6.5-8.0$ \\
\hline Particle size & $1 / 8-2$ inches \\
\hline Dry Matter & $5.5-8.0 \%$ \\
\hline$P$ & $0.35-0.41 \%$ \\
\hline
\end{tabular}

$\mathrm{mg} / \mathrm{ft}$. of tetracycline or Bavistin $250 \mathrm{~mL} / 100 \mathrm{~m}^{2}$ on the beds are quite effective (Eiri, 2018; Bahal, 2008).

\section{CONCLUSION}

Button mushroom is a delicious fungi and considered worldwide as healthy part of the human diet. Mushrooms have been used as food source since ancient times. Cultivation of edible mushrooms has significantly increased across America, Europe, and Asian countries. White button mushroom contains a wide range of nutritional components: ash (7.01 - 17.92\%), fibers (15.42 - $29.02 \%)$, proteins $(18.31-41.06 \%)$, fats $(1.54$ 5.38 ) and carbohydrates (28.38 - 34.88\%).

Agaricus bisporus is cultivated on compost containing organic nutrients and bacterial load. During the cultivation bacteria affects the yield, quality and nutritive value of button mushroom. Presently various agricultural wastes such as parali, sugar cane straw, paddy straw could be used for mushroom cultivation.

Bacteria has a vital role in composting and white button mushroom production. This review concluded that various types of bacteria have various roles in composting. Some of them could be harmful while others are useful. Detection of bacteria associated with turning needs future studies to understand their role in decomposing, mineralization and quality production of Agaricus bisporus.
Acknowledgments. I am grateful to the Dr. Arun Mishra for providing support to conduct academic research at SGVU, Jaipur, and Rajasthan, India. I also thank to the principal Dr. (Prof.) Sushil Kumar Sharma and Management of SGVU for continuous support and motivation.

\section{REFERENCES}

1. Abou-Zeid MA (2012). Pathogenic variation in isolates of Pseudomonas causing the brown blotch of cultivated mushroom, Agaricus bisporus. Brazilian Journal of Microbiology, 43(3): 1137-1146.

2. Andrade MC, Jesus JP, Vieira FR, Viana SR, Spoto MH, Minhoni T (2014). Effect of gamma irradiation on the nutritional quality of Agaricus bisporus strains cultivated in different composts. Anais da Academia Brasileira de Ciências, 86(2): 897-906.

3. Andrade MCND, Jesus JPFD, Vieira FR, Viana SRF, Spoto MHF, Minhoni MTDA (2013). Dynamics of the chemical composition and productivity of composts for the cultivation of Agaricus bisporus strains. Brazilian Journal of Microbiology, 44(4): 1139-1146.

4. Bahl N (2018). Handbook on mushrooms. Oxford \& IBH Publishing Co. PVT New Delhi, pp. 26-63.

5. Borkar SG, Nisha P (2016). Mushroom: a nutritive food and its cultivation. Daya Publishing House, pp. 4, 5-8 and 73-84.

6. Brinton WF (2000). Compost quality standards and guidelines. Final Report by Woods End Research Laboratories for the New York State Association of Recyclers.

7. Bull CT, De Boer SH, Denny, TP, Firrao G, Fischer-Le SM, Saddler GS, Takikawa Y (2012). List of new names of plant pathogenic bacteria (2008-2010). Journal of Plant Pathology, 94 (1): 21-27.

8. Changizi V, Angaji M, Zare MR, Abbasnejad K (2012). Evaluation of 226Ra, 232Th, 137Cs and 40K "Agaricus 
bisporus" activity in cultivated edible mushroom formed in Tehran Province-Iran. Iranian Journal of Medical Physics, 9(4): 239-244.

9. Choudhary DK (2011). First preliminary report on isolation and characterization ofnovel Acinetobacter spp. in casing soil used for cultivation of button mushroom, Agaricus bisporus (Lange) Imbach. International journal of microbiology. 2011: 1-6.

10. Chung IY, Kim YK, Cho YH (2014). Common virulence factors for Pseudomonas tolaasii pathogenesis in Agaricus and Arabidopsis. Research in microbiology, 165(2): 102109.

11. Cloonan KR, Andreadis SS, Chen H, Jenkins NE, Baker TC (2016). Attraction, oviposition and larval survival of the fungus gnat, Lycoriellaingenua, on fungal species isolated from adults, larvae, and mushroom compost. PloS One, 11(12): e0167074.

12. Dalzell HW, Biddlestone AJ, Gary KR, Thurairajan K (1987). Soil management: Compost production and use in tropical and subtropical environments FAO Soils Bulletin No 56. Andhra Pradesh, India. Medak Agricultural Centre, p. 193.

13. Eiri, (2018). Handbook of mushroom cultivation, processing, and packaging. Published by Engineers India Research Institute Delhi, pp. 28-65.

14. Gaur ACS, Neelakantan S, Dargan KS (2017). Organic manures. Indian Councilof agriculture Research, New Delhi, pp. 72-79, 149-153.

15. Gebeyehu R, Kibret M (2013). Microbiological and physicochemical analysis of compost and its effect on the yield of Kale (Brassica oleracea) in Bahir Dar, Ethiopia. Ethiopian Journal of Science and Technology, 6(2): 93-101.

16. Girisham S, Reddy SR, Charya MS (2012). Microbial Diversity: Exploration and Bioprospecting. Scientific Publishers, pp. 168-173, 224-237.

17. Gurtler JB, Doyle MP, Erickson MC, Jiang X, Millner P, Sharma M (2018). Composting to inactivate food borne pathogens for crop soil application: a review. Journal of food protection, 81(11): 1821-1837.

18. Jayaprakash S, Lohit HS, Abhilash BS (2018). Design and development of compost bin for Indian kitchen. Int J Waste Resour, 8(323): 2.

19. Johri BN (2011). Bacterial diversity in a bagasse-based compost prepared for the cultivation of edible mushrooms Agaricus bisporus. Journal of Agricultural Technology, 7(5): 1303-1311.

20. Jurak E, Punt AM, Arts W, Kabel MA, Gruppen H (2015). Fate of carbohydrates and lignin during composting and mycelium growth of Agaricus bisporus on wheat strawbased compost. PLoS One, 10(10): e0138909.

21. Jusoh MLC, Manaf LA, Latiff PA (2013). Composting of rice straw witheffective microorganisms (EM) and its influence on compost quality. Iranian journal of environmental health science \& engineering, 10(1): 17.

22. Keleș A, Koca I, Gençcelep H (2011). Antioxidant properties of wild edible mushrooms. Journal of Food Processing and Technology, 2(6).
23. Lechner P, Linzner R, Mostbauer P, Binner E, Smidt E (2005). Klimarelevanz der Kompostierung unter Berücksichtigung der Verfahrenstechnik und Kompostanwendung (KliKo). Endbericht im Auftrag der MA, p. 48.

24. Lim LY, Lee SC, Chew TL (2013). Composting and microbiological additive effects on composting. Environmental Science an Indian Journal, 8(9): 333-343.

25. Miyahara M, Kim SW, Fushinobu S, Takaki K, Yamada T, Watanabe A et al. (2010). Potential of aerobic denitrification by Pseudomonas stutzeri TR2to reduce nitrous oxide emissions from wastewater treatment plants. Applied and environmental microbiology, 76(14): 4619-4625.

26. Muszyńska B, Kała K, Rojowski J, Grzywacz A, Opoka W (2017). Composition and biological properties of Agaricus bisporus fruiting bodies-a review. Polish Journal of Foodland Nutrition Sciences, 67(3): 173-182.

27. Navarro MJ, Gea FJ (2014). Entomopathogenic nematodes for the control ofphorid and sciarid flies in mushroom crops. Pesquisa Agropecuária Brasileira, 49(1): 11-17. 29.

28. Pathak VN, Yadav N, Gaur M (2013). Mushroom production and processing technology. Agro bios (India), pp. 39-67.

29. Reddy SM, Babu GN, Reddy BV (2017). Applied Microbiology (Agriculture, Environmental, food \& industrial Microbiology). Scientific Publishers pp. 1-44, 360-381.

30. Roman P, Martinez MM, Pantoja A (2015). Farmer's compost handbook-Experiences in Latin America. Food and Agriculture Organization. http://www.fao.org/3/ai3388e.pdf

31. Rossiana N, Indrawati I, Mustika Y (2017). Application of vermicomposting, spent mushroom substrate, domestic compost and leachate as inoculum on bioremediation of oil sludge. Journal of Petroleum \& environmental biotechnology, 8: 6 .

32. Salmones D, Gaitan-Hernandez R, Mata G (2018). Cultivation of Mexican wildstrains of Agaricus bisporus, the button mushroom, under different growth conditionsin vitro and determination of their productivity. Biotechnologie, Agronomie, Sociétéet Environnement, 22(1): 45-53.

33. Sarkar PS, Chanda S (2016). Optimization of a vegetable waste compostingprocess with a significant thermophilic phase. Procedia Environmental Sciences, 35: 435-440.

34. Scialabba N, Gomez I, Thivant L (2017). Training manual of organic agriculture, Published by United Book Prints, pp. 52-55.

35. Silva CF, Azevedo RS, Braga C, Silva RD, Dias ES, Schwan RF (2009). Microbial diversity in a bagasse-based compost prepared for the production of Agaricus brasiliensis. Brazilian Journal of Microbiology, 40(3): 590-600.

36. Singh M, Vijay B, Kamal S, Wakchaure GC (2011). Mushrooms: cultivation, marketing and consumption. Mushrooms: cultivation, marketing and consumption. Directorate of Mushroom Research (Indian Council of Agricultural Research, Chambaghat, Solan, pp. 43-97. 
37. Singh S, Nain L (2014). Microorganisms in the conversion of agricultural wastesto compost. In Proc Indian Natn Sci Acad, 80(2): 473-481.

38. Singh SK, Jha PK (2014). Mushroom production and utilization. Scientific Publication, India, pp-1-20, 86-107.

39. Sinha SK, Upadhyay TK, Sharma SK (2020). Nutritional assessment of compost by SMC method for white button mushroom cultivation in Maharashtra. African Journal of Biological Sciences, 2(2): 16-24.

40. Smith JL, Collins HP (2007). Composting. In: Soil microbiology, ecology, and biochemistry (3rd edition), EA Paul, (Ed)., pp. 483-486. Academic Press, Burlington.

41. Siyoum NA, Surridge K, Korsten L (2010). Bacterial profiling of casing materials for white button mushrooms (Agaricus bisporus) using denaturing gradient gel electrophoresis. South African Journal of Science, 106(910): 1-6.

42. Sofi JA, Bangroo SA, Chesti MUH (2016). Practical manual for analysis of soil, water fertilizer and manure. Daya Publishing House, pp. 1-168.

43. Stanojević O, Milijašević-Marčić S, Potočnik I, Stepanović M, Dimkić I, Stanković S, Berić T (2016). Isolation and identification of Bacillus spp. from compost material, compost and mushroom casing soil active against Trichoderma spp. Archives of Biological Sciences, 68(4): 845-852.
44. Sundberg C, Yu D, Franke-Whittle I, Kauppi S, Smårs S, Insam H, Jönsson $\mathrm{H}$ (2013). Effects of $\mathrm{pH}$ and microbial composition on odour in food waste composting. Waste Management, 33(1): 204-211.

45. Swain MR, Laxminarayana K, Ray RC (2012). Phosphorus solubilization bythermo tolerant Bacillus subtilis isolated from cow dung micro flora. Agricultural Research, 1(3): 273-279.

46. Teshome B, Jabir A (2017). Evaluating methods of composting on date of maturity and quality of compost in Assosa, Western Ethopia. International journal of Waste Resources. 7: 4.

47. Verma BN, Prasad PK, Sahu KK (2013). Mushrooms: edible and medicinal. Daya Publishing House, pp 1-34.

48. Villar I, Alves D, Garrido J, Mato S (2016). Evolution of microbial dynamics during the maturation phase of the composting of different types of waste. Waste Management, 54: 83-92.

49. Wolna-Maruwka JD, Sawicka A (2009). Effect of temperature on the number of selected microorganism groups and enzymatic activity of sewage sludge compostedwith different additions in cybernetic. Agron. Res, 7(2): 875-890.

50. Zheng BX, Ibrahim M, Zhang DP, Bi QF, Li HZ, Zhou GW, Yang XR (2018). Identification and characterization of inorganic-phosphate-solubilizingbacteria from agricultural fields with a rapid isolation method. AMB express, 8(1): 47. 